\title{
Level Of Rice Production And Consumption In Maros Regency, South Sulawesi
}

\author{
Aulia Nurul Hikmah1, Laode Asrul2, Didi Rukmana², Sitti Bulkis², Mahyuddin², Rahmadanih² \\ ${ }^{1}$ Agribusiness Study Program, Graduate School of Hasanuddin University, Perintis Kemerdekan Km. 10 Makassar 90245, Indonesia. \\ ${ }^{2}$ Lecturer of Agribusiness Program, Postgraduate School of Hasanuddin University, Perintis Kemerdekan Km. 10 Makassar 90245, Indonesia.
}

Correspondence Author: Aulia Nurul Hikmah, Agribusiness Study Program, Graduate School of Hasanuddin University, Perintis Kemerdekan Km. 10 Makassar 90245, Indonesia.

Email: aulianurulhikmah@gmail.com, aulianurulhikmah@pasca.unhas.ac.id

Received date: 28 August 2019, Accepted date: 2 December 2019, Online date: 20 December 2019

Copyright: (c) 2019 Aulia Nurul Hikmah et al., This is an open-access article distributed under the terms of the Creative Commons Attribution License, which permits unrestricted use, distribution, and reproduction in any medium, provided the original author and source are credited.

\begin{abstract}
This research aims to describe the development of rice production and consumption in Maros Regency and analyze the factors affecting production in Maros Regency. The research used quantitative and qualitative methods. The sample consisted of 99 farming households. The data collected consisted of secondary and primary data. The secondary data were analyzed using qualitative descriptif and the primary data were analyzed using Cobb Douglass method through SPSS assistance program. The development of rice production in Maros Regency from 2007 to 2018 tended to increase every year with an average growth of $4.1 \%$ and a total average production of 192,859.07 tons. The average growth of rice consumption in Maros Regency from 2007 to 2018 was $4.2 \%$ with an average annual consumption of 30,903 tons. Factors that influence rice production in Maros Regency are area of land, seeds and fertilizer.
\end{abstract}

Keywords: Production, Consumption, Rice, Production Factors.

\section{INTRODUCTION}

Food needs will continue to increase as the population increases and consumption increases per capita. The highest population leads to an increase in rice consumption, could not be covered by the volume of national food production. This imbalance between food production and consumption has become a problem in many developing countries, such as Indonesia [1].

South Sulawesi is a Province that has an influence in the Indonesian economy, especially in economic growth. In 2017, the economic growth of South Sulawesi was $7.23 \%$. This is inseparable from the development of the agricultural sector, especially the subsector of food crops. One of the areas in the Province of South Sulawesi that makes agriculture one of the main sectors of its economy is Maros Regency. It can be seen in the contribution of the agricultural sector to the PDRB of the Regency of Maros, which is $17 \%$ [2].

Demographically, the regency of Maros had a population of 335.596 people in 2014 and increased to 349.882 people in 2018 . Faster population growth must be balanced with the good rice consumption. On the physical aspect, the area of paddy field in Maros Regency has decreased in 2015 of $26.002 \mathrm{Ha}$ to $25.952 \mathrm{Ha}$ in 2017 . These conditions will affect the production of rice commodities in Maros Regency. Increases and decreases in production can occur due to changes in the use of inputs applied by farmers. This research was conducted to analysis the development of rice production and consumption in Maros Regency over the past 12 years and to analysis the factors affecting rice production in Maros Regency.

\section{RESEARCH METHODS}

The research used quantitative and qualitative methods [3]. The sample in this study consisted of 99 farming households [4]. Descriptive analysis method is used to analysis the development of rice production and consumption in Maros Regency. The factors influencing the production of rice in Maros Regency are analysis using the Cobb Douglass method use the following analysis [5] :

$\operatorname{Ln} Y=\operatorname{Ln} \beta 0+\beta 1 \operatorname{Ln} X_{1}+\beta 2 \operatorname{Ln} X_{2}+\beta 3 \operatorname{Ln} X_{3}+\beta 4 \operatorname{Ln} X_{4}+\beta 5 \operatorname{Ln} X_{5}+\operatorname{Ln}_{\varepsilon}$

Information :

Y: Production of Rice 
$\mathrm{X}_{1}$ : Rice field area $(\mathrm{Ha})$

$\mathrm{X}_{2}$ : Fertilizers $(\mathrm{kg})$

$\mathrm{X}_{3}$ : Seed $(\mathrm{Kg})$

$\mathrm{X} 4$ : Pesticides (L)

X5: Labor (HOK)

$\beta 0$ : Interception or constant

$\beta 1,2,3,4,5$ : Regression coefficient

E: Error

\section{RESULTS AND DISCUSSION}

\section{A. Development of Rice Production and Consumption in Maros Regency}

The development of rice production and consumption in Maros Regency (Table 1) has fluctuates with a tendency to increase each year. This is due to increased productivity, adequate irrigation and the area of rice plants, so rice production in Maros regency is increasing. For 12 years, rice production in Maros regency has growth an average of $4.1 \%$ year with an average production of 192,859 tons per year. The local government has sought to increase rice production in Maros Regency. The effort was made by distributing subsidized fertilizers, and irrigation facilities were built and repaired, on a large, medium and small scale.

Table 1: Development of Rice Production and Consumption in Maros Regency

\begin{tabular}{|c|c|c|c|c|c|}
\hline Year & $\begin{array}{c}\text { Production of } \\
\text { rice (Ton) }\end{array}$ & $\begin{array}{c}\text { Growth } \\
(\mathbf{\%})\end{array}$ & $\begin{array}{c}\text { Consumption of } \\
\text { rice (Ton) }\end{array}$ & $\begin{array}{c}\text { Growth } \\
(\mathbf{\%})\end{array}$ & $\begin{array}{c}\text { Difference in } \\
\text { production and } \\
\text { consumption }\end{array}$ \\
\hline 2007 & $148.334,30$ & 0,0 & 27.171 & 0 & $127.163,30$ \\
\hline 2008 & $126.324,48$ & $-14,8$ & 28.788 & 5.95 & $97.536,48$ \\
\hline 2009 & $164.763,40$ & 30,4 & 28.746 & $-0,1$ & $136.017,40$ \\
\hline 2010 & $184.314,44$ & 11,9 & 29.200 & 1,6 & $155.114,44$ \\
\hline 2011 & $183.606,73$ & $-0,4$ & 28.365 & $-2,9$ & $155.241,73$ \\
\hline 2012 & $206.471,69$ & 12,5 & 28.302 & $-0,2$ & $178.169,69$ \\
\hline $\mathbf{2 0 0 7 - 2 0 1 2}$ & $\mathbf{1 6 8 . 9 6 9 , 1 7}$ & $\mathbf{7 , 9 1}$ & $\mathbf{2 8 . 4 2 8 , 6 7}$ & $\mathbf{0 , 8 6}$ & $\mathbf{1 4 1 . 5 4 0 , 5 1}$ \\
\hline 2013 & $198.787,30$ & $-3,7$ & 34.724 & 22,7 & $164.062,93$ \\
\hline 2014 & $230.092,05$ & 15,7 & 33.993 & $-2,1$ & $196.098,86$ \\
\hline 2015 & $220.323,43$ & $-4,2$ & 34.429 & 1,3 & $185.893,98$ \\
\hline 2016 & $196.986,03$ & $-10,6$ & 31.037 & $-9,9$ & $165.949,00$ \\
\hline 2017 & $233.988,83$ & 18,8 & 34.084 & 9,8 & $199.904,74$ \\
\hline 2018 & $220.316,19$ & $-5,8$ & 31.993 & $-6,1$ & $188.322,98$ \\
\hline $\mathbf{2 0 1 3 - 2 0 1 8}$ & $\mathbf{2 1 6 . 7 4 8 , 9 7}$ & $\mathbf{2 , 7 7}$ & $\mathbf{3 3 . 3 7 6 , 8 9}$ & $\mathbf{- 1 , 1 7}$ & $\mathbf{1 8 3 . 3 7 2 , 0 8}$ \\
\hline Average & $\mathbf{1 9 2 . 8 5 9 , 0 7}$ & $\mathbf{4 , 1}$ & $\mathbf{3 0 . 9 0 3}$ & $\mathbf{4 , 2}$ & $\mathbf{1 6 1 . 9 5 6 , 3 1}$ \\
\hline
\end{tabular}

Source : Secondary data after processing, 2019.

During the 2007-2018 period, the average growth of rice consumption in Maros regency was $4.2 \%$ per year with an average annual consumption of 30,903 tons. The decrease in rice consumption in Maros regency was due to the displacement of the population in Maros regency which had been consumers of rice to become consumers of non-rice. The rate of growth of rice consumption in Maros regency has decreased every decade to reach a negative number, which shows a change in the tastes of consumers of rice to a more diversified product (Table 1).

\section{B. Effect of factors of production on rice production in Maros regency}

Results of data processing on factors affecting rice production in Maros Regency (Table 2)

Table 2: Values of the regression coefficients and input variables for rice production in Maros Regency, 2019

\begin{tabular}{|c|c|c|c|c|}
\hline No. & Variables Input (Xi) & Coefficients & t-count & Significant \\
\hline 1. & Rice Field Area & 0,939 & 3,331 & 0,001 \\
\hline 2. & Fertilizers & 0,189 & 2,801 & 0,005 \\
\hline 3. & Seed & 0,761 & 3,537 & 0,001 \\
\hline 4. & Pesticides & 0,057 & 0,755 & 0,452 \\
\hline 5 & Labor & 0,112 & 0,380 \\
\hline \multicolumn{4}{|c|}{ f-count $=6.341$} \\
t-table $=1,986$ & f-table $=2.380$ \\
\hline
\end{tabular}

Source : Primary data after processing, 2019. 
The correlation coefficient (R) of 0.876 means that variables such as land area, amount of seeds, fertilizers, pesticides and labor contributed $87.6 \%$ to rice production in Maros Regency. Value of $f_{\text {count }}>f_{\text {table }}$ at the $95 \%$ confidence level (6,341> 2,380), which means that the overall independent variable significantly influences the production of rice products (Table 2). The equation for the Cobb Douglass method use the following analysis :

\section{$\operatorname{Ln} Y=2,004+0.939 \operatorname{Ln} X_{1}+0.189 \operatorname{Ln} X_{2}+0.761 \operatorname{Ln} X_{3}+0.057 \operatorname{Ln} X_{4}+0.112 \operatorname{Ln} X_{5}$}

The results of the calculation of the elasticity of rice production reached 2.058. The number of elasticity values more than one indicates that this is happening Increasing return to scale. This value implies that adding one percent of each production factor together will increase production of rice products by 2.058 percent. The elasticity value of the production factor of the rice fielad area area (X1) is the most influential among the other production factors if it is observed from the quantity of elasticity.

\section{Rice Field Area $\left(\mathbf{X}_{1}\right)$}

Table 2: Partial t-test

\begin{tabular}{|c|c|c|c|}
\hline Independent Variable & T count & T table & Significant \\
\hline Rice Field Area $\left(\mathrm{X}_{1}\right)$ & 3,331 & 1,986 & 0,001 \\
\hline
\end{tabular}

Source : Primary data after processing, 2019.

Rice field area use affects the production of rice by t-count (3.3301) > t- table (1.986) with a significance value of 0,001 . The value of rice filed area coefficient of 0,939 explains that if an increase rice field area by 1 unit will increase the production of rice by $0,939 \mathrm{~kg}[6]$.

\section{Fertilizers $\left(\mathbf{X}_{2}\right)$}

Table 3: Partial t-test

\begin{tabular}{|c|c|c|c|}
\hline Independent Variable & T count & T table & Significant \\
\hline Fertilizers $\left(\mathrm{X}_{2}\right)$ & 2,801 & 1,986 & 0,005 \\
\hline
\end{tabular}

Source : Primary data after processing, 2019.

Fertilizers use affects the production of rice by $t$-count $(2,801)>t$ - table $(1,986)$ with a significance value of 0,005 . The value of Fertilizers coefficient of 0,189 explains that if an increase fertilizers by 1 unit will increase the production of rice by 0,189 $\mathrm{kg}$.

\section{Seed $\left(\mathbf{X}_{3}\right)$}

Table 4: Partial t-test

\begin{tabular}{|c|c|c|c|}
\hline Independent Variable & T count & T table & Significant \\
\hline Seed $\left(\mathrm{X}_{3}\right)$ & 3,537 & 1,986 & 0,001 \\
\hline
\end{tabular}

Source : Primary data after processing, 2019.

Seed use affects the production of rice by t-count $(3,537)>t$ - table $(1,986)$ with a significance value of 0,001 . The value of seed coefficient of 0,761 explains that if an increase seed by 1 unit will increase the production of rice by $0,761 \mathrm{~kg}$.

4. Pesticides $\left(\mathrm{X}_{4}\right)$

Table 5: Partial t-test

\begin{tabular}{|c|c|c|c|}
\hline Independent Variable & T count & T table & Significant \\
\hline Pesticides $\left(\mathrm{X}_{4}\right)$ & 0,755 & 1,986 & 0,452 \\
\hline
\end{tabular}

Source : Primary data after processing, 2019.

Pesticides use has not significant effect on increasing rice production by t-count $(0,755)>\mathrm{t}$ - table $(1,986)$ with a significance value of 0,452 . The value of pesticides coefficient of 0,057 explains that if an increase pesticides by 1 unit will increase the production of rice by $0,057 \mathrm{~kg}$.

\section{Labor $\left(\mathbf{X}_{5}\right)$}

Table 6: Partial t-test

\begin{tabular}{|c|c|c|c|}
\hline Independent Variable & T count & T table & Significant \\
\hline Labor $\left(\mathrm{X}_{5}\right)$ & 0,380 & 1,986 & 0,705 \\
\hline
\end{tabular}

Source : Primary data after processing, 2019. 
Labor use has not significant effect on increasing rice production by $t$-count $(0,380)>t$ - table $(1,986)$ with a significance value of 0,705 . The value of labor coefficient of 0,112 explains that if an increase labor by 1 unit will increase the production of rice by $0,112 \mathrm{~kg}$.

\section{CONCLUSION}

1. The development of rice production in Maros Regency from 2007 to 2018 tended to increase every year with an average growth of $4.1 \%$ and a total average production of 192,859.07 tons. The average growth of rice consumption in Maros regency from 2007 to 2018 was $4.2 \%$ with an average annual consumption of 30,903 tons.

2. Factors that influence rice production in Maros Regency are land size, seeds and fertilizers. These three variables have a significant influence on rice production in Maros Regency

\section{REFERENCES}

[1] Jumriani Dambe,Didi Rukmana,Mahyuddin,Sitti Nurani Sirajuddin. 2019. Volatility Of Rice Prices In South Sulawesi. American-Eurasian Journal of Sustainable Agriculture. ISSN : 1995-0748, EISSN: 1998-1074 2019, Volume (13), Issue (2) : Pages (55-60)

[2] Khumaidi, M. 1997. Beras Sebagai Pangan Pokok Utama Bangsa Indonesia, Keunikan dan Tantangannya. Dalam Orasi Ilmiah. Fakultas Pertanian Institut Pertanian Bogor.

[3] BPS. 2017. Statistik daerah Provinsi Sulawesi Selatan. Badan Pusat Statistik Sulawesi Selatan : Makassar

[4] Nurhapsa, Nunung Kusnadi, Muhammad Firdaus and Sitti Nurani Sirajuddin. 2014. Factors Affecting Farmer's Productivity New Potato Yield Varieties. American-Eurasian Journal of Sustainable Agriculture. ISSN : 1995-0748, Volume (8), Issue (2) : pages 52-57

[5] Sarwono, Jonathan. 2006. Metode Penelitian Kuantitatif dan Kualitatif. Yogyakarta : Penerbit Graha Ilmu.

[6] Amirin, T. 2001. Populasi dan Sampel Penelitian 4 : Ukuran Sampel Rumus Slovin. Erlangga. Jakarta

[7] Soekartawi. 2003. Teori Ekonomi Produksi dengan Pokok bahasan Analisis Fungsi Cobb-Douglas. PT. Raja Grafindo Persada. Jakarta.

[8] Siwitri Munambar, Masyhuri, Jangkung HM, Lestari Rahayu W. 2019. The Demand forRice and The Factors That Influence inThe Special Region of Yogyakarta. American-Eurasian Journal Of Sustainable Agriculture. ISSN:1995-0748, EISSN: 1998-1074 2019, Volume (13), Issue (1) : Pages (18-21)

[9] Sitti Nurani Sirajuddin, Indriati Sudirman, Lydia Devega Bahar, Abdel Rahman Al Tawaha, and Abdel Razzaq Al-Tawaha. 2018. Social economic factors that affect cattle farmer's willingness to pay for artificial insemination programs. Bulgarian Journal of Agricultural Science, 24 (No 4) 2018, 574-580

[10] Syamsinar, Amal, Sitti Nurani Sirajuddin. 2015. Analysis of Factors Associated with the Size of Receipt Reinvestment Cocoa Farming. American-Eurasian Journal Of Sustainable Agriculture. ISSN: 1995-0748, EISSN: 1998-10742015, volume (9),issue (4):pages (8-14)

[11] Irene Kartika Eka Wijayanti, Jamhari, Dwidjono Hadi Darwanto, Any Suryantini. 2019. Production Risk and Factors Influencing Strawberry Farming in Purbalingga Regency, Indonesia. American-Eurasian Journal Of Sustainable Agriculture. ISSN : 1995-0748, EISSN: 1998-1074 2019, Volume (13), Issue (1) : Pages (9-17). 